UDK: 62:929 CURIE I; CURIE M.

COSATI: $07-02,18-08,18-02$

\title{
Marie and Irene Curie, Mother and Daughter, Two Ladies, Three Nobel Awards
}

\author{
Miroslav Jandrić ${ }^{1)}$ \\ Dimitrije Dimić ${ }^{2)}$
}

\begin{abstract}
It has been 150 years since Marie was born, and 120 years since Irene was born, mother and daughter Curie, two ladies who dedicated their lives to science and were awarded three Nobel prizes. Marie Sklodowska Curie was not only the first female to receive the Nobel award, but also the first person to receive the award two times, and the only women to receive the awards for two different areas of science (physics and chemistry). Irene Jolio Curie, having inherited the genetic code of her parents and with enormous scientific effort and dedication, received her own Nobel Prize from chemistry. Marie and Irene, women of Slavic descent, paved the way for other women in science and education, with a sheer power of their minds, in times when little attention was paid to women's education.
\end{abstract}

There are people who over-exceed the time they live in, with their abilities and ways of life. These are the personages who are capable of tremendous mental and physical efforts, able to achieve incredible results. These people possess pronounced ambition and unusual passion for creation and work. One of these rare persons, who stepped away from the mediocrity so extremely was Marie Curie, woman who left indelible mark on global science and earned her place among the greats of science. She was probably the only one who, in her ascetic dedication to science, came close to the immortal Serbian genius scientist Nikola Tesla.

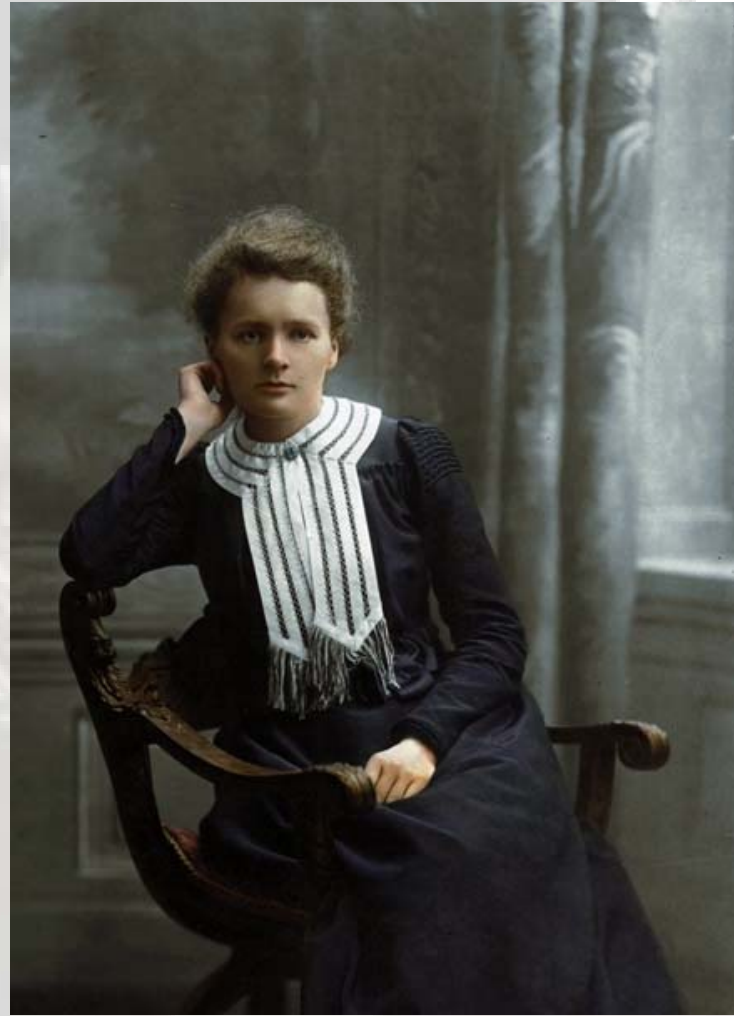

Figure 1. Marie Sklodowska Curie (1867 - 1934)

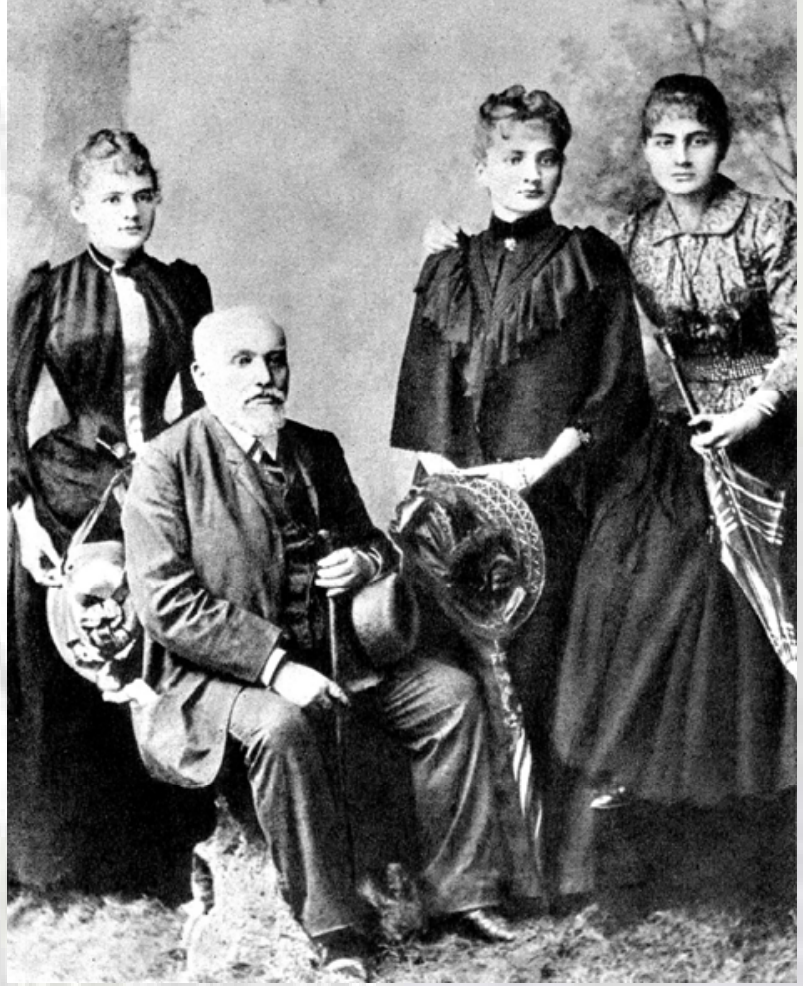

Figure 2. Marie (first on the left) with father Wladyslaw and sisters Zofia and Bronislawa

Marie Sklodowska Curie was born in Warsaw, Poland, on November 7, 1867. Her parents were intellectuals dedicated to education. Father Wladyslaw was a professor of physics and mathematics, and mother, a pedagogue and director of a prestigious boarding school for girls. Besides Marie, who wasthe youngest, they had four more children. At the time Poland was divided between two empires, Russia and Austria. Being too much of a Pole was not advisable at the time, so her father lost his job in 1876. As it is usually the case, one misfortune pulls along the others, and Marie's eldest sister Zofia died of typhoid fever, and almost twelve years later her mother died from tuberculosis [1-3].

\footnotetext{
1) Military Technical Institute (VTI), Ratka Resanovića 1, 11132 Belgrade, SERBIA

2) NORTAL, Lõõtsa St 6c, Tallinn 11415, ESTONIA

Correspondence to: Miroslav Jandrić; e-mail: jami953@yahoo.com
} 
Having finished state gymnasium, where, like her brother Jozef and sister Bronislawa, she received the golden medal for demonstrated knowledge, Marie started supporting herself by holding private classes. Since university was not allowing women at the time in Poland, her older sister Bronislawa left for Paris to study medicine. To financially aid her sister, Marie found an employment as a tutor to a noble family of Żorawskis from Krakow (1886). Here she fell in love with her employer's son Kazimierz, future prominent mathematician. Due to class differences, his parents forbade the relationship and Marie lost not only her love, but also her job $[1,2,13]$.

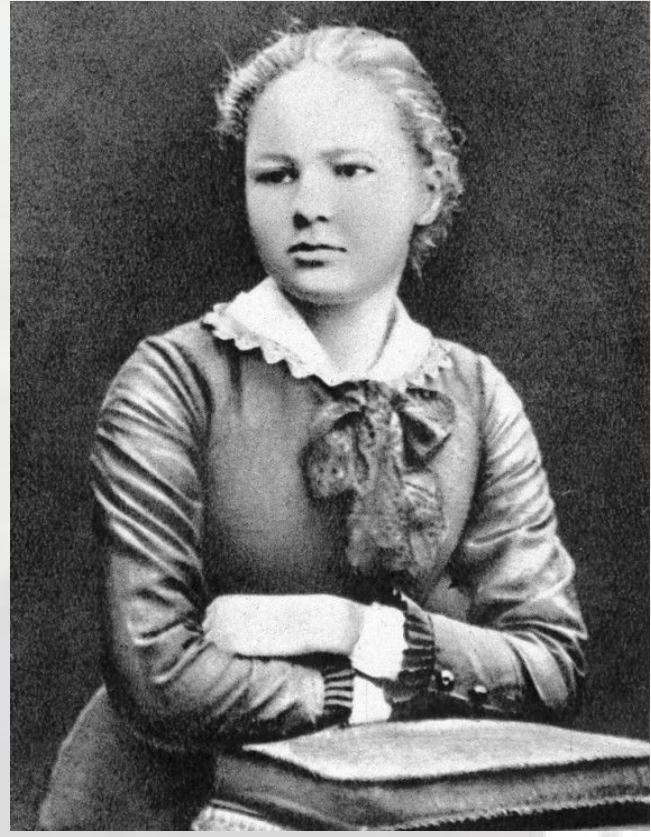

Figure 3. Marie in Krakow - 1886

In October 1891, upon the invitation of her sister Bronislawa, who in the meantime married a colleague from the studies, Marie left for Paris. She enrolled the Sorbonne University, thus attaining her longtime youthful dream. Living at the first time with her sister, and then by herself, in modest, cold and unbecoming apartments, often saving on food and seriously risking her health, she spent her student days in an absolute commitment to the studies. This self-imposed, strenuous work regime, gave results and in 1893, she graduated in physical and chemical sciences as the best and first in her generation, and next year as the second best in generation, she graduated in mathematical sciences.

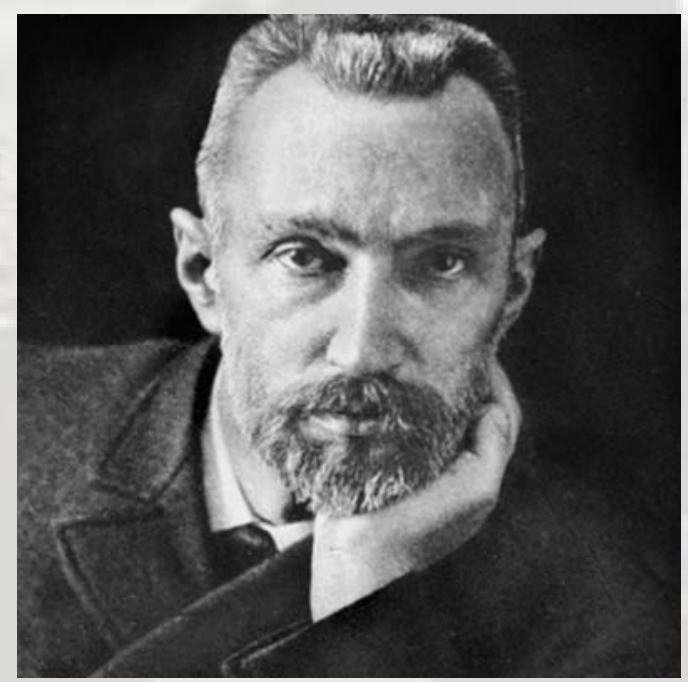

Figure 4. Pierre Curie (1859 - 1906)
During her studies, she was employed as a laboratory technician at Lippmann Industrial Laboratory, to supplement her modest scholarship. At the suggestion of the owner of the laboratory, the discoverer of color photography, Gabriel Lippmann (1845-1921), Marie was doing her first scientific work titled "The Magnetic Properties of Hardened Steel". This work opened the door of the School of Industrial Physics and Chemistry, where in 1894 she met her future spouse Pierre Curie (1859-1906), a brilliant French physicist who was already known for discovering piezoelectricity in 1880 with his brother Jack [1-4,11].

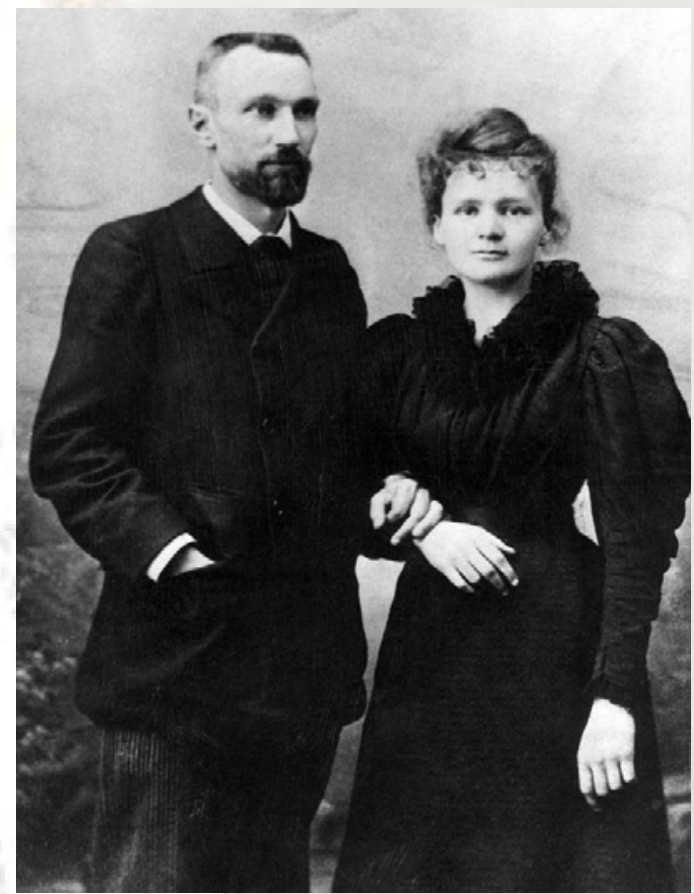

Figure 5. Marie and Pierre after their wedding - 1895

As at the beginning of his Sonnet 116, the great and unprecedented Shakespeare says: "There is no reason why two great minds would not be merged into marriage," after a year of acquaintance and mutual intellectual and emotional affection, in 1895, Marie and Pierre got married. In the same year, Pierre received his doctorate in the field of magnetism, in which he proved that iron-based magnetic materials lose their magnetic properties if heated at a certain temperature - that temperature, that critical point, is now called the Curie point $[3,4,13]$.

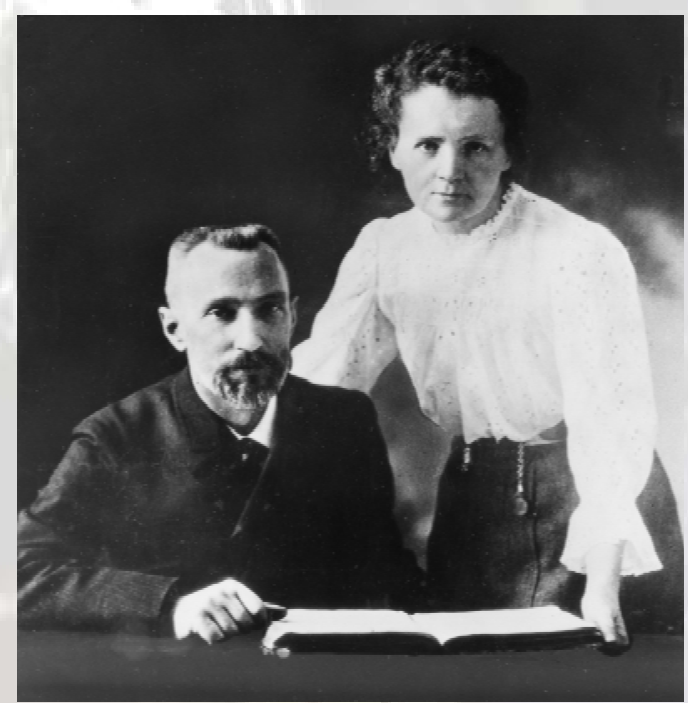

Figure 6. Marie and Pierre - 1899 
Pierre introduced Marie to his mentor Becquerel (Antoine Henry Becquerel, 1852-1921) who discovered, in 1896 , that uranium salts emit invisible rays that are very penetrating as well as X-rays. Encouraged by this discovery, Marie decided to study uranium rays as a part of her doctoral dissertation. Already, at the very beginning of her research, she proved that the radiation strength is proportional to the amount of uranium, and that the radiation is not influenced by the chemical composition or the external circumstance, but that the radiation comes from the atom itself. Further research has found that such activity of uranium compounds is characteristic (Uraninite - oxide of uranium - $\mathrm{UO}_{2}$ ) for some other substances as well (Thorium), so she decided to call this phenomenon "radioactivity". Then, with Pierre's help, she discovered two new highly radioactive chemical elements, polonium in July 1898, and radium in December of the same year [5] .

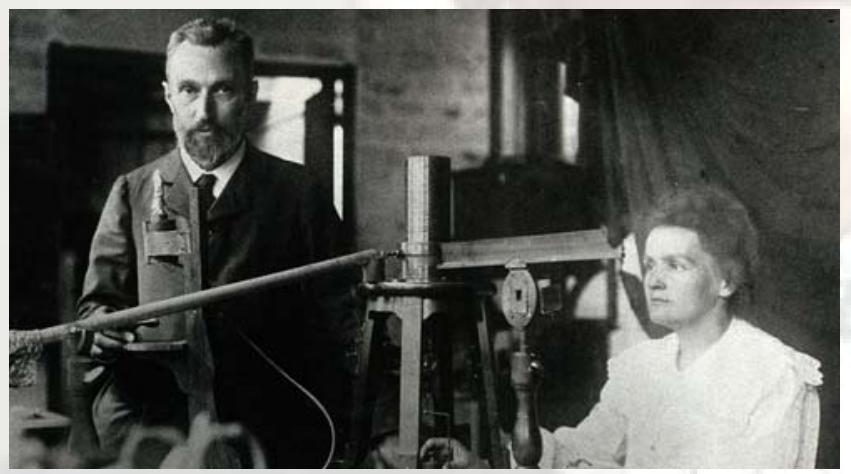

Figure 7. Marie and Pierre in the laboratory

Polonium (Po) was named after Marie's homeland of Poland. It is a rare radioactive silver-white heavy metal from VIa group of the Periodic System, with atomic number 84 . It occurs in minerals containing radium, in the form of isotopes with mass numbers in the range of 192218. Only Po-210 can be found in nature, with a half-life of 138 days, while the most stable is Po-209 with a half-life of 102 years. Its melting point is at about 254 degrees $C$, and has a density of $9196 \mathrm{~kg} / \mathrm{m}^{3}[6,7,9]$.
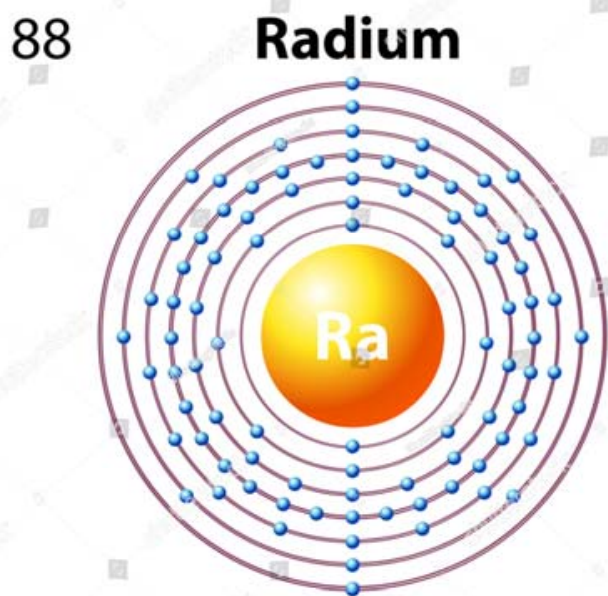

Atomic mass: 226

Electron configuration: $2,8,18,32,18,8,2$

Figure 8. Schematic view of the radium with mass number 226

Radium ( $\mathrm{Ra}$ ) was named after its extremely high radioactivity. It is a naturally occurring silvery-white radioactive chemical element with atomic number 88 . It belongs to a group of alkaline earth metals, melts at about 700 degrees $\mathrm{C}$, and has a density of $5500 \mathrm{~kg} / \mathrm{m} 3$. It appears in the form of isotopes with mass numbers in the range 206232. The most common and stable is Ra-226, with a halflife of 1620 years $[6-8,10]$.

However, many world-renowned chemists were skeptical of the existence of radium, although Marie's former professor and employer Gabriel Lippmann announced it at a lecture at the French Academy of Sciences (Académie des Sciences) on April 12, 1898, when he informed the wider scientific community of her research work. In order to silence the skeptical part of the scientific community the Curies, thanks to the advocacy of Professor Suess and the Vienna Academy of Sciences, received the ore from the Austro-Hungary, which originated from the Czech mine Joachimsthal, and begun to separate the radium. Their painstaking work gave results, and in autumn 1902, after processing 8 tons of Uranium ore, they managed to isolate 1 decigram of pure radium, of atomic weight 225 [6-11].

In the period from 1899 to 1904, Marie and Pierre together, individually or with one of their associates, published 32 scientific papers. In 1901, the foundations of "Curietherapy" in medicine were established, based on the discovery of the effect of radiation on the cells. It has been discovered that diseased, carcinogenic cells are much more quickly destroyed if they are exposed to radiation than a healthy cell. In order to allow their further experimental work on the treatment of cancer cells, they sought financial assistance from many. The biggest help was obtained from the US President Harding, who donated 1 gram of radium on behalf of American women. This discovery played an enormous role in further research and development of the treatment therapy of many forms of cancer. Radiological therapy is still one of the main therapeutic methods in the treatment of cancerous diseases [1,2,12].



Figure 9. Marie and Pierre in the moments of rest

On June 25, 1903, Marie Curie defended her doctoral dissertation entitled "Testing of Radioactive Substances", in which, among other things, she provided her understanding of the structure of radioactive radiation. Members of the commission, including Lippman (Nobel Prize winner for physics in 1908) and Moissan (Nobel Prize winner for chemistry in 1906), were both impressed by her knowledge and the quality of her dissertation based on the 
experimental results. She thus became the first woman with the title of Doctor of Physics, as well as the first woman to reach that level of academic education in France $[1,2,10]$.

It seemed that doors of the world-class science were now open to Marie. But this time was not very favorable for women, not even for women such as Marie Curie and Mileva Maric Einstein. Swedish mathematician and fighter for women's rights in science Magnus Gustaf Mittag warned Pierre that the Nobel Committee intends to award the Nobel Prize in physics only to him and Becquerel for radiation research. Good Pierre was so angry that his letter of objection to the committee was written in such a tone that the Nobel Committee on December 10, 1903 awarded the Nobel Prize to a woman for the first time. That year the Nobel for Physics was awarded to Becquerel for the discovery of radiation, and to Pierre and Marie for a special contribution to the study and application of the phenomenon of radiation.

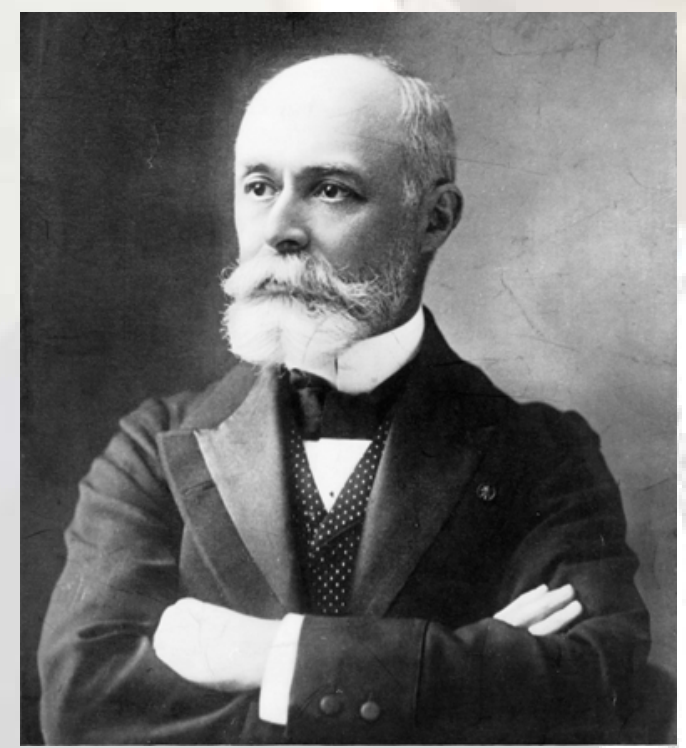

Figure 10. Antoine Henry Becquerel (1852 - 1921)

After she became a widow on April 19, 1906, because Pierre died under the wheels of a heavy horse-drawn cart, on May 13 of the same year the Council of the Natural Sciences Faculty unanimously decided to give the Department of Physics, which Pierre held since 1900, to Marie. In this fashion she became the first female university professor at Sorbonne. Her first lecture, which was of a great interest, began with the same sentence with which Pierre completed his last. At that time, she was the only one in the world who held lectures on radioactivity, and wrote the corresponding textbook $[1,2,12]$.

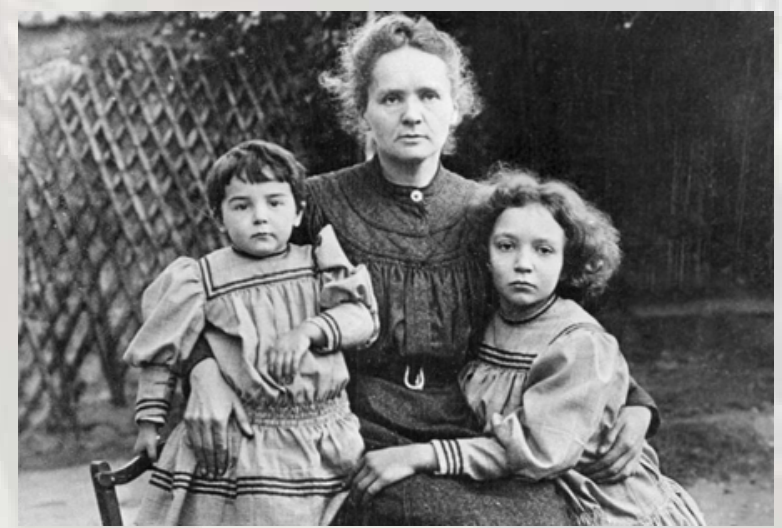

Figure 11. Marie remains alone with her daughters Irene and Eve after Pierre's death - 1906
The obligations of the university professor did not prevent her from continuing to engage in research in the field of radioactivity. With the help of her associates, and above all Andre Louis Debierne (who discovered the Actinium in 1899), in 1910 for the first time she was able to isolate pure radium metal. Immediately after, she discovered a method for measuring the amount of radium, based on the measurement of the amount of its emanation radon.

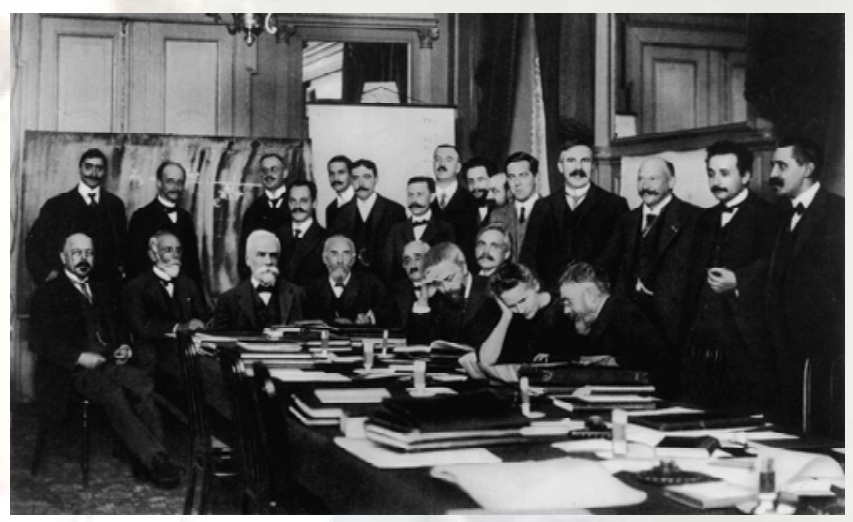

Figure 12. Marie Curie was the only female physics attendant on the 1911 Conference in Solvay

Despite the enormous scientific contribution and achievements in early 1911, her application for the French Academy of Sciences was rejected on the grounds that members of the academy could not be women. The offered Legion of Honor was rejected. But at the end of that same year, her strenuous work was rewarded with another Nobel Prize, but this time for chemistry. The Nobel Committee, in its explanation for awarding the prestigious recognition, stated that Marie Curie was attributed to the discovery of elements of polonium, radium, as well as for the isolation of the radium and the study of the nature of this extraordinary element. This time, she did not share the Nobel Prize, but received it as an individual and thus became the first double laureate. By gaining another Nobel Prize, many barriers and obstacles in her scientific work, which were often personal in nature, started falling. Thanks to the wider social and material support of the public, the "Institute for Radium" (now Curie Institute) was founded in Paris in 1914, and Marie became its first director. In the following years this institute produced four Nobel laureates $[1,9,10]$.


Figure 13. Nobel Prize in chemistry for the year of 1911 was awarded to Marie Sklodowska Curie

Further research by Marie found out that roentgen rays can help detect and locate foreign objects in the body, making the operation performed by the surgeon significantly easier. This discovery came to full expression 
in wartime surgery during the World War I. With the help of her older daughter Irene, whom she introduced to scientific activities relating to the medical application of radiography, she designed a medical vehicle that was used for radiography. Out of affection, this special vehicle was called "Little Curie". These vehicles were fitted with an Xray machine, and assisted surgeons in the detection of shrapnel and bullets in the bodies of the wounded. In this way, the wounds of about 3 million wounded French were more easily treated. The International Red Cross appointed Marie to the head of their radiological center with the responsibility to train as many specialists as possible, to work with X-rays as the new medical technique. Soon after, around 200 mobile and stationary radiological stations were established $[1-4,13,14]$.

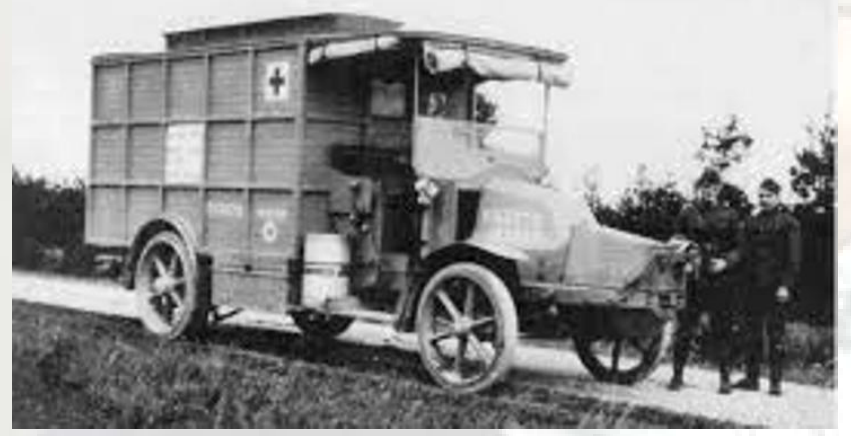

Figure 14. Reno's medical vehicle with roentgen device (Little Curie)

Upon the end of the war, Marie returned to her scientific work at the Institute. In addition to working in the institute, she also held lectures around the world. She arrived to the United States where the President Hoover handed her $\$ 50,000$ donation for procurement of radium. She was received to the French Academy of Sciences in 1922, although she did not even submit the application for candidacy. It was a rectification of injustice and a late acknowledgment that a great injustice was done to her $[1,12,23]$.

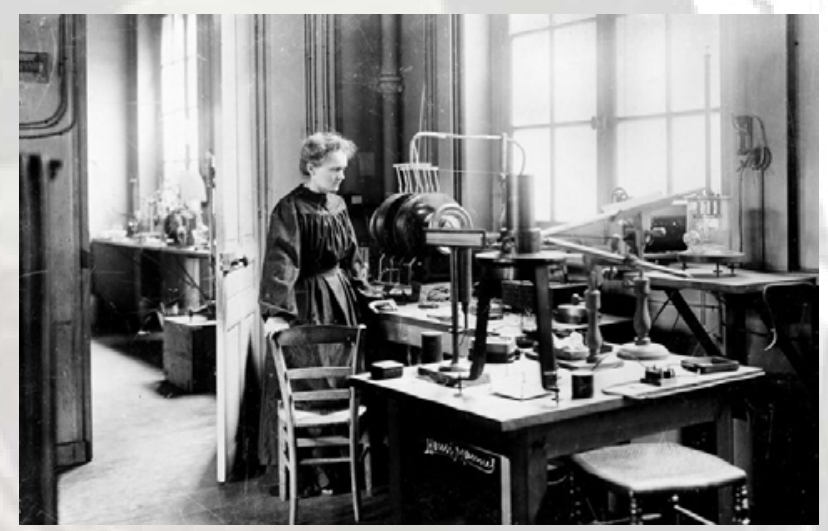

Figure 15. Marie in the laboratory

However, there were health problems. First she had problems with the kidneys and eyes, then bile. Her blood cell count was getting worse, and painful burn-marks appeared on her hands. Marie Curie died on July 4, 1934, at the age of 66, at the Sancellemoz sanatorium. A direct cause was aplastic anemia (leukemia), which was the result of a long-term exposure to radiation, for which harmful effects were not yet known. It is believed that in addition to laboratory equipment, even the books and notes that Marie used, will not be safe to use for at least 1500 years, and will continue to be stored in lead bins by then. She was interred next to her husband Pierre at the cemetery in Sceaux. In 1995, their remains were transferred to the Paris Pantheon cemetery to a tomb reserved only for the most distinguished personalities of France, for persons whose actions and work did not only elevate France, but also the entire humanity [2-4,23].

Mankind owes to Marie and Pierre so much. Their genius, scientific work, the absence of self-promotion, envy and greed, in times when their first isolated gram of radium could bring an incredible fortune, but was instead donated, is their legacy to the world. The world paid them an homage by naming a chemical element curium $(\mathrm{Cm})$, with an atomic number of 96 , after them. Also, the radioactivity measurement unit Curie $(\mathrm{Ci})$, which is defined as the number of decays in 1 second of 1 gram of pure radium, was named after them. Later, in the system of measuring units SI, the Curie unit was replaced by the Becquerel unit $(\mathrm{Bq})$, although it is still in an unofficial use today.



Figure 16. Marie Sklodowska Curie, the only woman who was awarded two Nobel Prizes for two different science areas (physics and chemistry)

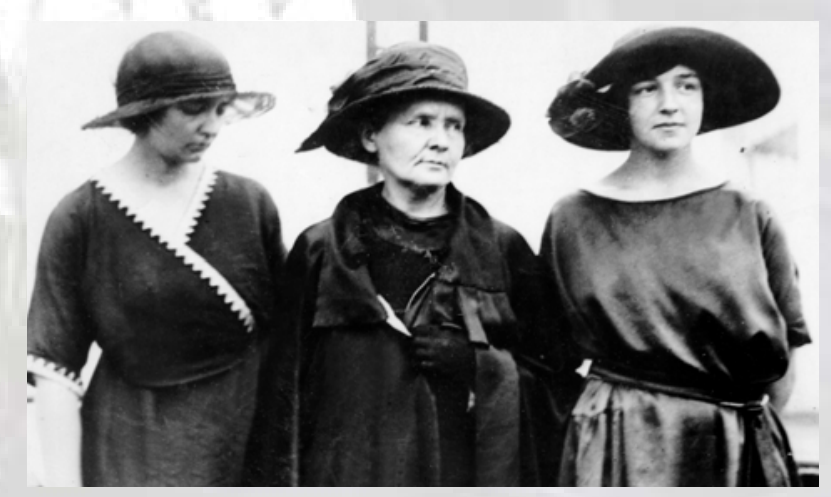

Figure 17. Marie with daughters Irene (left) and Eve (right)

All of their scientific papers were most often started with the words "we found...", "we came to the knowledge of...", "one of us..." and the like. However, Marie and Pierre were not only connected by the love of learning, working, researching and discovering something new, but also by mutual commitment, love and passion. Pierre, as eight years her senior, with manners of an experienced man, awakened and stimulated the thinnest, most subtle and the most intimate 
spiritual and physical feelings of love, that women of Slavic descent can show and give to the man they care about. From this love, marked by a complete and unreserved commitment, two daughters were born, first Irene on September 12, 1897, and then Eve on December 6, 1904 [1-4,13].

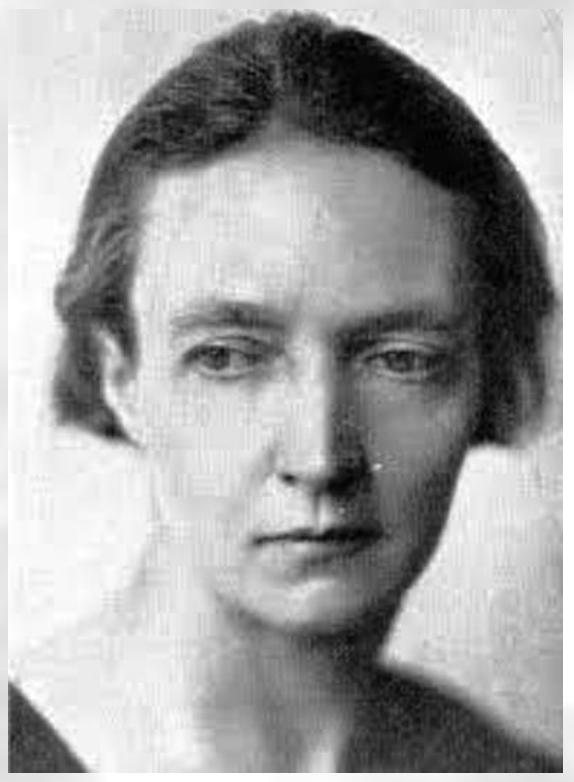

Figure 18. Irene Jolio Curie (1897 - 1956)

Eve later became a respectable music critic, talented pianist and distinguished writer who in 1937 wrote her mother's biography titled "Madam Curie". She was married to a famous lawyer and diplomat Henry R. Labouisse, who dealt with social politics and problems. In 1965, as the executive director of UNICEF, he received the Nobel Peace Prize on behalf of the organization $[3,23]$.

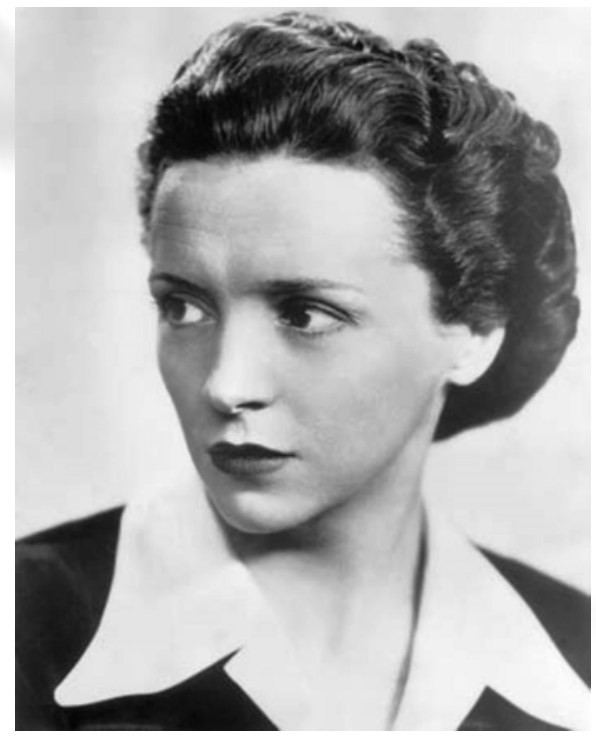

Figure 19. Eve Curie (1904. - 2007.)

Irene was turned toward natural sciences and moved in her parents' steps. She continued her family tradition in pursuing physics and chemistry. Her studies at the Sorbonne were interrupted due to the World War I. During the war, she was engaged as a nurse-radiographer in a medical team formed by her mother Marie. After the war she continued her studies, and in 1925 she received a Doctorate at Sorbonne in the field of radioactivity, with the topic "Radiation of alpha particles from the polonium". Working on the experimental part of her dissertation at the Institute for Radium (Curie Institute), she met a colleague and assistant Frederic Joliot, whom she married in 1926 and gave birth to their son Pierre Joliot and daughter Helene Joliot, who continued their family's scientific tradition. Pierre, as a biophysicist, became a member of the French Academy of Sciences in 1982, and Helen became an outstanding physicist and professor [3,14,23].

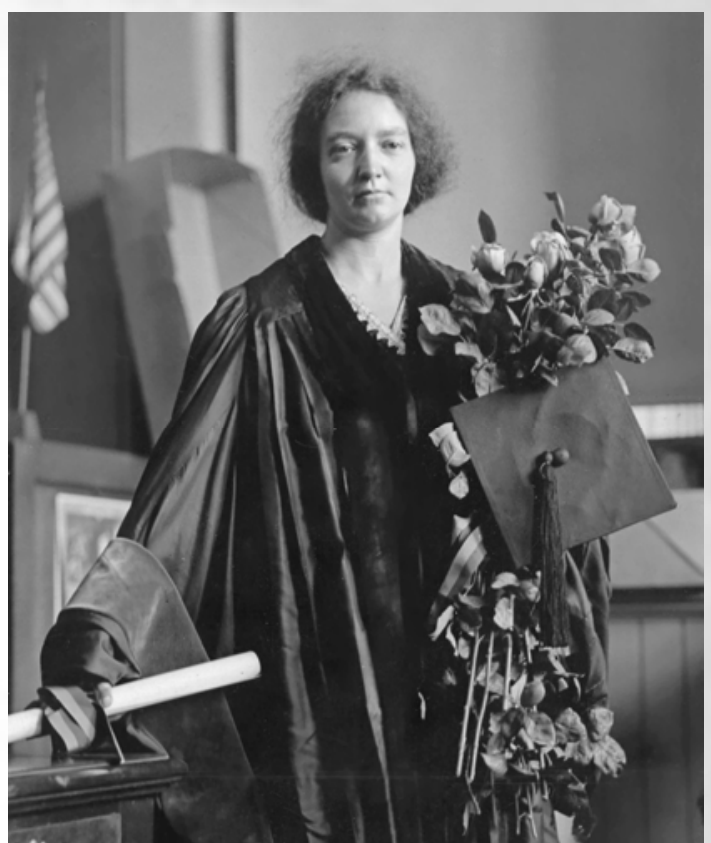

Figure 20. Irene received her $\mathrm{PhD}$ from Sorbonne in 1925

The married couple and researchers, Irena and Frederic, continued Marie and Pierre's research into the phenomenon of radioactivity at the Institute for radium, first under the leadership of Marie, and later independently. They were engaged in nuclear physics, and in particular they were interested in the field of artificial radioactivity discovered in 1934 by bombarding aluminum, boron and magnesium with alpha particles for the production of isotopes of nitrogen, phosphorus, silicon and aluminum. The following year they received the Nobel Prize in Chemistry for the synthesis of new radioactive elements, that is, for the invention of artificial radioactivity. The results of their experimental research were an introduction to the discovery of nuclear fission $[14,15]$.

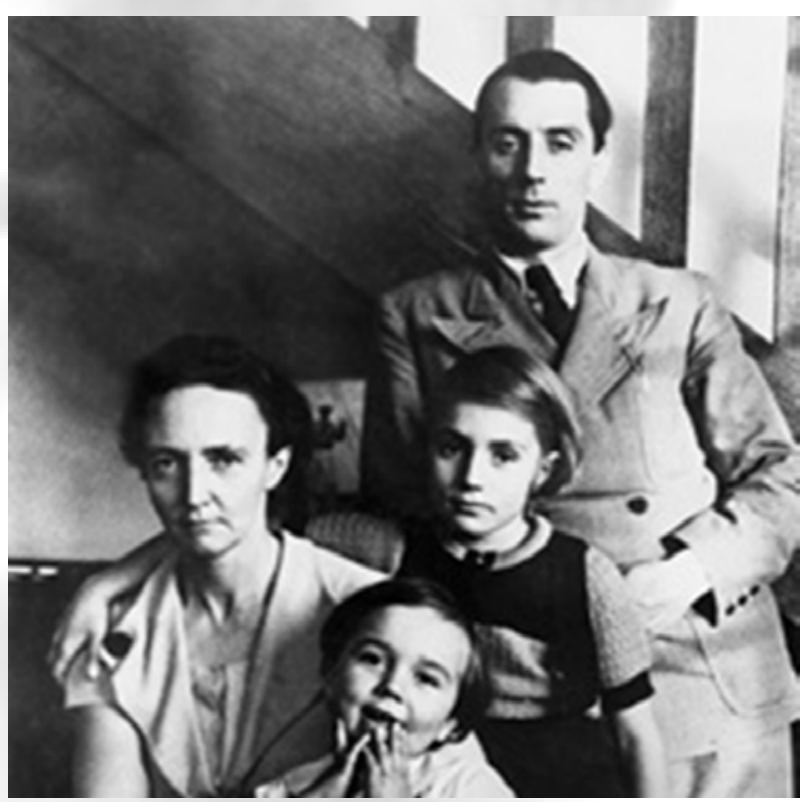

Figure 21. Irene and Frederick with daughter Helene and son Pierre 
Having received their Nobel Prize, Irene and Frederic became the second married couple, after Marie and Pierre, who, for joint work, received the most prestigious scientific recognition. Two of them were adorned with one great feature, in addition to the undeniable scientific talent, they were always open to cooperate with other researchers. In 1935, a young Serbian physicist and chemist, Pavle Savić (1909-1994), became Irene's associate, whose six-month scholarship by the French government was continually extended on her proposal, for to five years of cooperation, or until the beginning of the World War II [16,19-21].

Irene suggested to Pavle to work with her on the problem of the origin of radioactivity due to the neutron effect on uranium, which was observed one year ago by Italian physicist Enrico Fermi and his associates. Pavle accepted the proposal, and in 1937 and 1938, using the slow neutrons they bombard uranium atoms leading to the discovery of isotopes of known elements. After two years of an intensive research, in addition to nine already known, they also detected the tenth radioactivity. On that occasion, unknown atoms with a lower regular number and half-life of 3.5 hours (also called R3.5h) were discovered, but they were not identified as isotopes of lanthanum. Lanthanum in the Mendeleev's periodic system is assigned a serial number of 57 , which is 35 places behind the uranium. This practically meant the discovery of a nuclear reaction that would later be called nuclear fission.

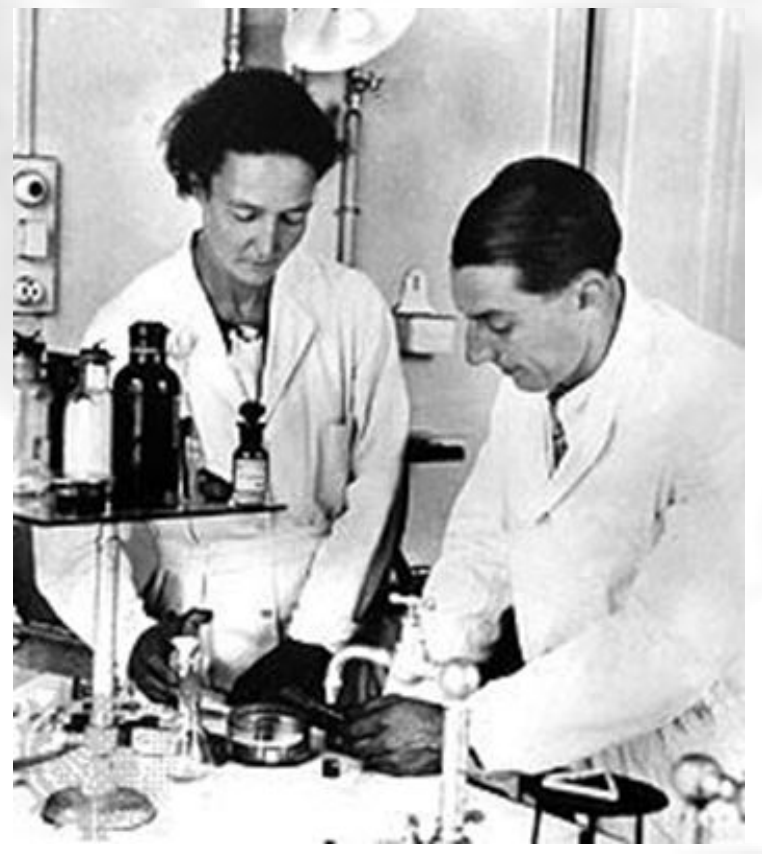

Figure 22. Irene and Frederick in the laboratory of the Institute for radium

In the Proceedings of the French Academy of Sciences (Comptes rendus de l'Académie des Sciences) in September 1938, Irena and Pavle published a co-authorship related to the effects of neutron on heavy nuclei. This was considered to be the basic work for the discovery of nuclear fission. They did not stop here, but continued their research work and in 1939, at the Institute for Radium, they worked on determining a neutron-efficient cross section for uranium fission, which later became the basic procedure for calculating chain reaction in nuclear reactors and nuclear weapons [7,20,21].

At the same time, a group of German scientists in Berlin, led by Otto Hahn, also dealt with the same problem, as Irene and Pavle did. This radiochemist wrote a letter to Irene's husband, Nobel Prize-winner Frederic Joliot, in which he urged him to plead with the authors to deny and withdraw the work because they presented "impossible and wrong results". Otherwise, he would be "forced" to deny them publicly, which would be very unpleasant for him because Irene is his wife and the winner of the Nobel Prize.

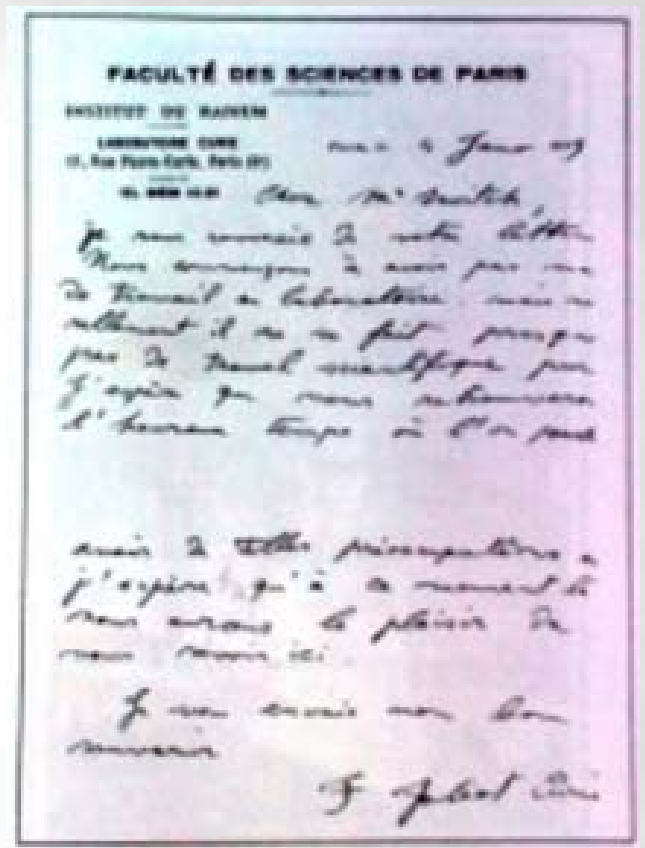

Figure 23. One of the Irene's letters to Pavle in which she thanks him for the cooperation

Two scientists, confident in their work and their scientific integrity, did not deny the results. In an attempt to refute Irene and Pavle's results, Otto Hahn and his primary associates, Friedrich Strasmann and Lise Meitner, at the end of January 1939, however, had to admit that the published results were accurate and that the radioactivity of 3.5 hours relates to a single lanthanum isotope. On this occasion, they found another radioactivity that fully belonged to the adjacent element - barium. This led to the discovery of nuclear fission - the splitting of the uranium core $[4,20-22]$.

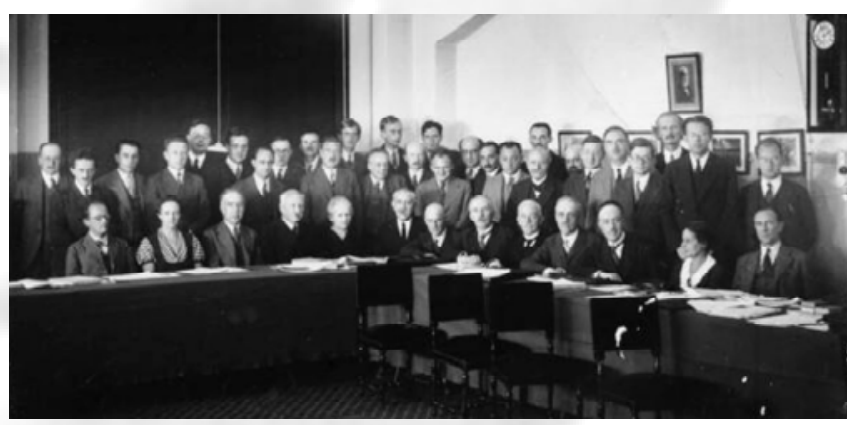

Figure 24. On the Solvay physics conference in 1933 there were three women present, Irene Jolio Curie, Marie Sklodowska Curie and Lise Meitner (from left to right)

In the end, everything was pointing that Irena Jolio-Curie and Pavle Savić would receive the Nobel Prize. Under the pretext of the World War II breaking out, the prize was not awarded, and yet in 1944 Nobel was awarded to Otto Hahn, who proved their assumption that radioactivity sprang from lanthanum. It is interesting to note that during the war, the Nobel Prize for chemistry was given to Adolf Butenandt, Leopold Ruzicka - 1939, and Gérard de Hevesyre - 1943. In truth, it must be said that the Nobel Prize was not awarded during the war in 1940, 1941, and 1942. 




Figure 25. Irene in laboratory

Perhaps one of the reasons for such an outcome of the Nobel Prize award ceremony lies in the fact that, unlike Marie and Pierre, who lived and worked in an isolated world of laboratory and scientific research, Irene and Frederick were very politically engaged. Deeply aware of the dangers of overturning fascism, they became very active members of the left-wing "French Socialist Party". Irene was also a member of the Women's Committee against Fascism and War Committee, in 1936 was elected to the Undersecretary for Science in the French People's Front Government. Frederick joined the Resistance Movement during the war, and in 1942 he became a member of the Communist Party of France [14,18].

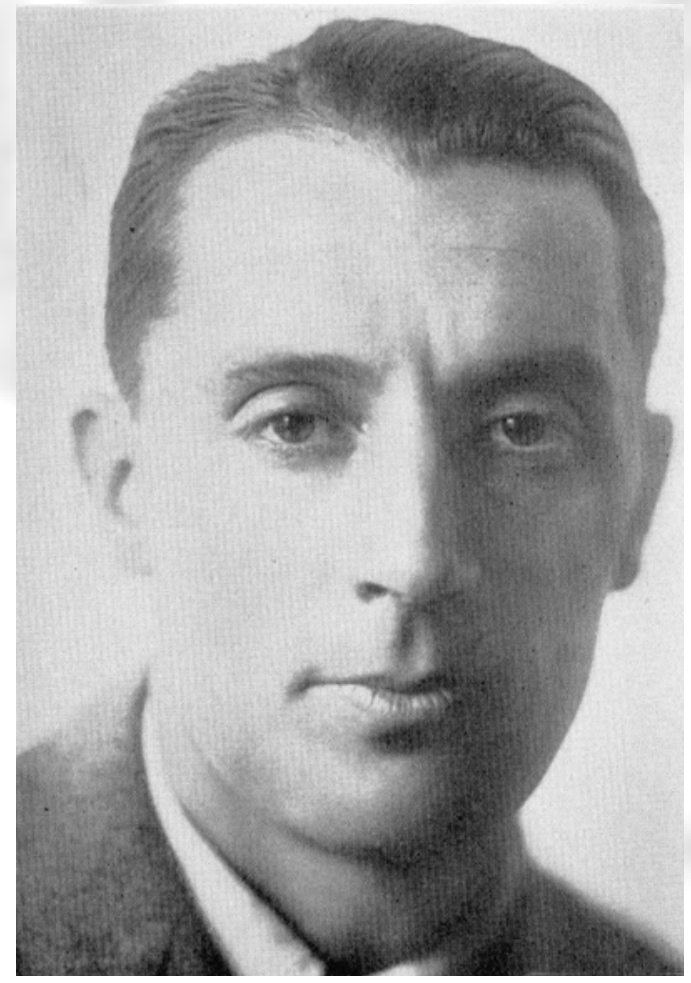

Figure 26. Frederick Jolio (1900 - 1958)

Immediately after the war, Irene and Pierre became the leading members of the French Atomic Energy Commission and participated in the construction and definition of the French nuclear and civilian military program. However, due to their socialist beliefs, in 1951 they were forced to leave work at the Atomic Energy Commission. Harassing treatment went so far that in 1953, the American Chemical Society refused to accept Irene to their membership on the grounds that her political commitments were unacceptable for the "Western democracy".

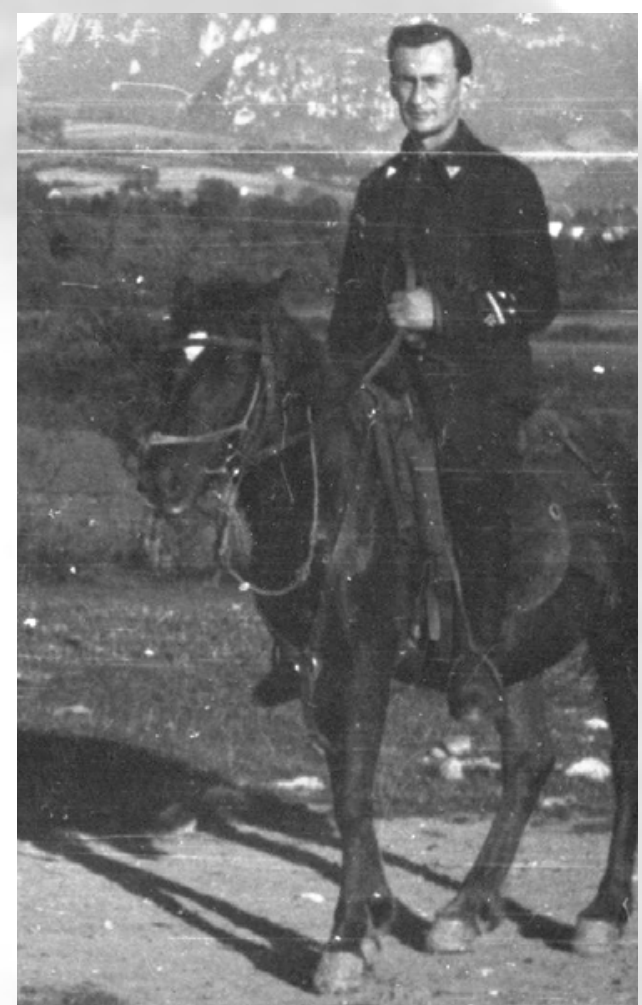

Figure 27. Pavle Savić, 1943, in the uniform of the Yugoslav partisans

If we add that Pavle Savić, during his stay in Paris, became a member of the Communist Party of Yugoslavia, on Josip Broz Tito's personal recommendation, and that this is why he was expelled from France in 1939, on the grounds that he was helping the volunteers in the Spanish Civil War, then the games surrounding the Nobel Prize unveil another, non-scientific meaning. During the war Pavle Savic was the head cipher officer as well as the head of the radio station at the Supreme Headquarters of the Yugoslav Partisans. Before the end of the war he was sent to Moscow where, until 1947, he worked in the Institute of Physics together with one of the greatest Russian and world scientists of all time, Academician Pyotr Leonidovich Kapitsa, on the development of the Soviet nuclear technology. During 1947 he returned to Belgrade where he began working on the formation of the Yugoslav Institute of Nuclear Sciences. He was the director of the worldrenowned institute "Vinca" until 1960, and after that, until his retirement, he was dedicated to a professorship at the Belgrade University. In the period from 1971 to 1981 he was the president of the Serbian Academy of Sciences and Arts. He died and was buried in Belgrade in 1994 [14,22].

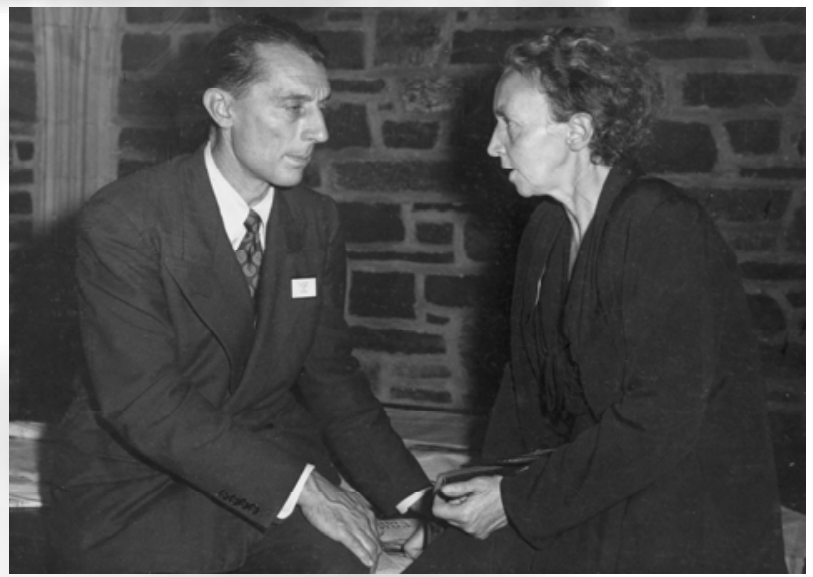

Figure 30. One of the last joint photographs of Irene and Frederick 
Irene Curie was a professor at Sorbonne, an honorary doctor of sciences at several universities, she was named the Officer of the Legion of Honor, and since 1946 she was the director of the Institute for Radium, an institute founded by her mother Marie. She died on March 17, 1956, of leukemia, a consequence of the radiation she was exposed to during her scientific research. Her friend, comrade, scientist and life-fellow, her love, her husband, joined her on her way without return on August 14, 1958 [3,23].

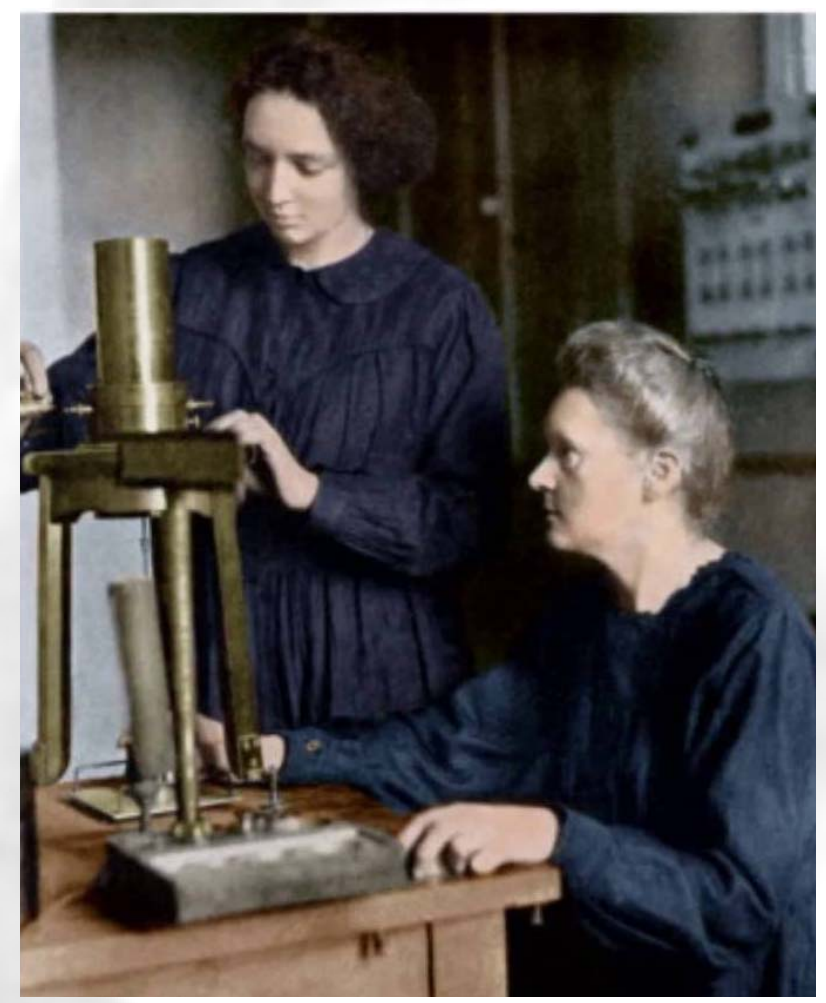

Figure 28. Marie and Irene performing their research together

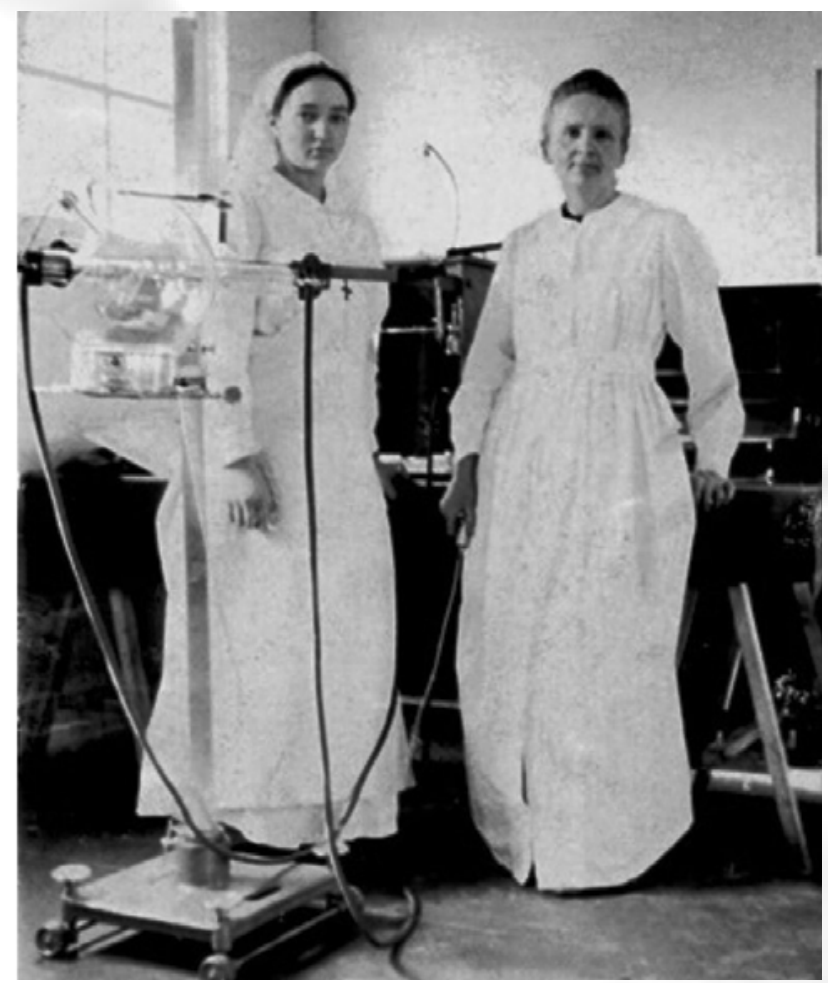

Figure 29. Marie and Irene Curie at the time of the World War I
Regardless of the recognition she received for the scientific research work and the political functions she occupied, Irene remained somewhat in the shadow of her mother. She did not have Marie's charisma nor life and scientific fanaticism that bordered on self-destruction, but took a subtler way to reach her goals. However, it is beyond doubt that Marie and Irene Curie, mother and daughter, were scientists whose scientific achievements marked the first half of the twentieth century, and that is why the Scientific Technical Review journal dedicates this publishing year to them.

\section{Literatura}

[1] KIRI,E.: Marija Kiri - Biografija, Matica srpska, Novi Sad, YUGOSLAVIJA (SERBIA), 1949

[2] CURIE,E.: Madame Curie: A biography, Da Capo Press, 2001, ISBN 978-0-306-81038-1.

[3] BRAIN,D.: The Curies: A Biography of the Most Controversial Family in Science, John Wiley and Sons, Inc., 2005, New York, SAD, ISBN 978-0-471-27391

[4] REDNISS,L.: Radioactive: Marie \& Pierre Curie - a Tale of Love and Fallout, Harper Collins, 2010, ISBN 978-0-06-135132-7.

[5] WALTON,H.F.: The Curie - Becquerel Story, Journal of Chemical Education, ISSN 0021-9584, 1992, Vol.69, No.1, pp.10-15

[6] FROMAN,N.: Marie and Pierre Curie and the Discovery of Polonium and Radium, www.nobelprize.org

[7] GUILLAUMONT,R., GRAMBOW,B.: Chemistry after the Discoveries of Polonium and Radium, Chemistry International, ISSN 0193-6484, January-February 2011, Vol.33, No.1, pp.24-27.

[8] Radijum, www.sh.wikipedia.rg/wiki/Radijum

[9] Polonijum, www.sh.wikipedia.rg/wiki/Polonijum

[10] Illustration of the element Radium, www.shutterstock.com

[11] BÉNSUADE-VINCENT,B.: Marie Curie, femme de science et de légende, Revev de Palais de la découverte, avril 1988, Vol.116, No.157, pp.15-30

[12] KAUfFMAN,G.B.: Marie Curie's Relations with the United States, Chemistry International, ISSN 0193-6484, January-February 2011, Vol.33, No.1, pp.16-19.

[13] DINČIĆ,N.: Marija Sklodovska Kiri, Svet Nauke, www.svetnauke.org (26.09.2010).

[14] ПОПОВИЋ,Д.: На фронту сусретања Марије Кири и Лизе Мајтнер, Књиженство, ISSN 2217-7809, 2015.

[15] JOLIOT-CURIE,I., JOLIOT,F.: The Emission of High Energy Photons from Hydrogenous Irradiated with Very Penetrating Alpha Rays, Comptes Rendus, 194:273, 1932

[16] L'ANNUNZITA,M.F.: Radioactivity: Introduction and History, Elsivier, 2007, ISBN 978-0-444-52715-8, pp.98-105

[17] JOLIOT-CURIE,I., SAVITCH,P.: Radioelement of period 3.5 hours formed from uranium bombarded by neutrons, Comptes Rendus, 206: 906 and 1643, 1938.

[18] GOLDSMITH,M.: Frederic Joliot-Curie: A Biography, Lawrence \& Wilshart, 1976, London, GB, ISBN 0-85315-342-6

[19] Irène Joliot, la otra Curie tam bién gandora del Nobel de Quimica, www.de10.com.mx

[20] GILMER,P.J.: Irene Joliot-Curie, A Nobel Laureate in Artifical Radioactivity, www.chem.fsu.edu

[21] GARAŠANIN,M. (urednik): Zbornik u čast Pavla Savića povodom sedamdesetogodišnjice rođenja, SANU, Beograd, SERBIA, 1980.

[22] BRACIĆ,M.: SAVIĆ,P.: Astronomski Magazin, www.astronomija.org.rs, (30.07.2017).

[23] MITIĆ,M.: Marija i Irena: Majka i ćerka u službi nauke, www.iserbia.rs, 23.01.2017 


\section{Marija i Irena Kiri, majka i ćerka, dve dame, a tri Nobela}

Prošlo je 150 godina od rođenja Marije i 120 godina od rođenja Irene, majke i ćerke Kiri, dve dame koje su svoje živote posvetile nauci i za to nagrađene sa tri Nobela. Marija Sklodovski (Sklodowska) Kiri nije samo prva žena koja je dobila Nobelovu nagradu, već je i prva osoba koja je tu nagradu dobila dva puta i jedina žena koja ju je dobila za dve različite naučne oblasti (fizika i hemija). Irena Žolio (Jolio) Kiri nasledivši genetski kod svojih roditelja, a i uz veliki naučni trud i rad iz hemije dobija svog Nobela. Marija i Irena, žene slovenskog porekla, naučnim radom su se bavile u vremenu kada se obrazovanju žena nije posvećivala baš neka velika pažnja pa su snagom svog intelektualnog uma istovremeno krčile $i$ obrazovne i naučne puteve i drugim ženama.

\section{Мария и Ирена Кюри, мать и дочь, две женщины и три Нобелевские премии}

Прошло 150 лет со дня рождения Марии и 130 лет со дня рождения Ирены, матери и дочери Кюри, двух женщин, которые посвятили свою жизнь науке и за заслуги получили награды - три Нобелевские премии. Мария Склодовская (Skłodowska) Кюри - не только первая женщина в мире, получившая Нобелевскую премию, но является и первым человеком вообще, получившим эту награду дважды, и единственной женщиной, которая её получила за две разные области науки (физика и химия). Ирена Жолио (Јоlio) Кюри, унаследовав генетический код своих родителей, и с большим научным усилием и работой по химии, получает Нобелевскую премию. Мария и Ирена, женщины славянского происхождения, занимались научной работой в то время, когда на образование женщин не обращали особого внимания, и с учётом их интеллектуального разума одновременно сокращались образовательные и научные пути для других женщин.

\section{Marie et Irène Curie, mère et fille, deux dames et trois prix Nobel}

Il y a 150 ans depuis la naissance de Marie Curie et 120 depuis la naissance d'Irène, mère et fille Curie, deux dames qui ont consacré leur vie à la science et pour cela elles ont obtenu trois prix Nobel. Marie Sklodowska Curie est non seulement la première femme à obtenir le prix Nobel mais aussi la première personne à obtenir deux prix Nobel et la seule femme à l'avoir pour deux différents domaines scientifiques (physique et chimie). Irène Joliot-Curie, héritière du code génétique de ses parents, par un grand effort scientifique et le travail du domaine de chimie, a eu son Nobel. Marie et Irène, femmes d'origine slave, s'occupaient du travail scientifique à l'époque où l'on ne prêtait pas l'attention à l'éducation des femmes et elles ont par la force de leur intelligence ouvert les voies éducatives et scientifiques pour toutes les autres femmes. 